\title{
COMPARATIVE HYGIENIC ASSESSMENT OF PESTICIDES BEHAVIOR IN SOIL IN INTENSIVE GRAIN FARMING TECHNOLOGIES
}

10.36740/WLek202010113

\author{
Anna V. Blagaia, Mykola V. Kondratiuk, Sergii T. Omelchuk, Ihor M. Pelo, Nataliia D. Kozak \\ BOGOMOLETS NATIONAL MEDICAL UNIVERSITY, KYIV, UKRAINE
}

\begin{abstract}
The aim: Was the comparative hygienic evaluation of the pesticide behavior in the soil after application on cereals.

Material and methods: Methods of full-scale in-field hygienic experiment, high-performance liquid (HPLC), gas-liquid (GLC), thin-layer chromatography, statistical, bibliography were used in the research.

Results: Data on the detailed conditions and land parcels treated with studied pesticide formulation and its a.i. are highlighted in the article. The actual levels of the different classes a.i. content in soil and its dynamics were determined, based on which the dissipation rate constants $(K)$ were calculated, as well as quantitative parameters of stability $(\tau 50$, т95, т99).

Conclusions: Azoxystrobin, benzovindiflupyr, epoxiconazole, propiconazole, prochloraz, cyproconazole can be classified as of low hazardous substances, and trinexapac-ethyl, kresoxim-methyl, picoxystrobin, and tebuconazole are considered to be moderately hazardous. Among all pesticides studied, tebuconazole is the longest persists in the soil; epoxiconazole and propiconazole are most likely to disappear from the soil. Calculated values of half-lives of the studied substances in the agro-climatic conditions of Ukraine are slightly different from the results of in-field experiments that were conducted in other countries, namely: azoxystrobin, epoxiconazole, propiconazole, and cyproconazole disappear from the soil more quickly; the kresoxim-methyl and pinoxaden disappear more slowly. Meanwhile, the persistence of benzovindiflupyr, picoxystrobin, prochloraz, trinexapac-ethyl, and tebuconazole does not differ from the persistence in soils of European countries.
\end{abstract}

KEY WORDS: soil dynamics, persistence, plant protection, hygiene

Wiad Lek. 2020;73(10):2175-2180

\section{INTRODUCTION}

Every year, as a result of increasing both the quantitative use of chemical protection products of plants and their qualitative diversity, the likelihood of pesticidal load on environmental objects and the risk of accumulation of their residues, migration along trophic chains of food increases. [1-3]. For humans, this can lead to direct danger through the contamination of plants and plant products with pesticide residues. The most contaminated object of the biosphere is soil that can be repeatedly contaminated during the season or for many years. Therefore, soil from a sanitary and hygienic point of view is a potential place for the longest and most massive accumulation of plant protection chemicals. Contamination of soil by compounds of different chemical classes can lead to disruption of the life of microorganisms, the processes of recovery and soil formation may also be distorted [4]. It should also be taken into account that after repeated use of pesticides, the composition of microflora capable of biotransforming and decomposing these substances is disturbed. This all leads to a decrease in the target effect of pesticide formulations and the effectiveness of active ingredients (a.i.) in the fight against crop pests falls clearly [5-8]. However, with the same biological activity of the active substances against the target objects, the criteria for their selection should be human safety and environmental safety.

\section{THE AIM}

The purpose of the work was the comparative hygienic evaluation of the behavior of active substances of chemical plant protection products in the soil after application on cereals.

\section{MATERIALS AND METHODS}

Methods of full-scale in-field hygienic experiment, high-performance liquid (HPLC), gas-liquid (GLC), thin-layer chromatography, statistical, bibliography were used in the research.

Data on studied formulations (F.) \#1-9, land parcels types are given in table 1.

Sampling was carried out in accordance with the "Uniform Rules for Sampling of Agricultural Products, Foodstuffs and Environmental Objects to Determine Micro-Quantities of Pesticides".

Cereal crops were treated using a MZU-320 sprayer connected to a UMZ tractor (F. 8), and using an OPSh-2000 sprayer connected to MTZ-82 tractor (F. 1, F. 4, F. 5, F. 6, F. 9, F. 2), Landini-2000 (F. 7), MTZ-80 (F. 3) or using a hinged spray drier mounted on the AeroS-2 trike (F. 1, F. 6 ).

For a more detailed determination of the behavioral characteristics of a.i. of pesticides in the environment, we conducted full-scale in-field studies in different agro-climatic zones of Ukraine, which are characterized by different types of soils. 
Table 1. In-field conditions for the research of studied formulations [9]

\begin{tabular}{|c|c|c|}
\hline $\begin{array}{l}\text { Number of } \\
\text { land parcel }\end{array}$ & $\begin{array}{l}\text { Location of the site / } \\
\text { formulation }\end{array}$ & Soil type \\
\hline \multicolumn{3}{|r|}{ Forest-Steppe, Right Bank Province } \\
\hline 1. & $\begin{array}{c}49^{\circ} 48^{\prime} 17^{\prime \prime} \mathrm{N} \\
29^{\circ} 46^{\prime} 04^{\prime \prime} \mathrm{E} \\
2\end{array}$ & Chernozems podzolized + Chernozems deep, low humus, leached (Chernic) \\
\hline 2. & $\begin{array}{c}49^{\circ} 56^{\prime} 42^{\prime \prime} \mathrm{N} \\
30^{\circ} 12^{\prime} 40^{\prime \prime} \mathrm{E} \\
3\end{array}$ & Chernozems deep, low humus, leached \\
\hline 3. & $\begin{array}{c}49^{\circ} 47^{\prime} 59^{\prime \prime} \mathrm{N} \\
30^{\circ} 00^{\prime} 04^{\prime \prime} \mathrm{E} \\
4\end{array}$ & Chernozems typical, very goodhumus-accumulating \\
\hline 4. & $\begin{array}{c}50^{\circ} 20^{\prime} 24^{\prime \prime} \mathrm{N} \\
30^{\circ} 25^{\prime} 22^{\prime \prime} \mathrm{E} \\
9\end{array}$ & $\begin{array}{c}\text { Gray forest moderately to low humusacumulative + Dark gray podzolized medium } \\
\text { humus accumulative }\end{array}$ \\
\hline 5. & $\begin{array}{c}49^{\circ} 36^{\prime} 29^{\prime \prime} \mathrm{N} \\
28^{\circ} 05^{\prime} 51^{\prime \prime} \mathrm{E} \\
5\end{array}$ & Chernozems typical moderately high humusacumulative \\
\hline 6. & $\begin{array}{c}49^{\circ} 21^{\prime} 07^{\prime \prime} \mathrm{N} \\
27^{\circ} 21^{\prime} 15^{\prime \prime} \mathrm{E} \\
1,6\end{array}$ & $\begin{array}{l}\text { Dark gray podzolized medium humus accumulative }+ \text { Chernozems podzolized } \\
\text { medium to high humusacumulative }\end{array}$ \\
\hline \multicolumn{3}{|r|}{ Forest-Steppe, Left Bank Lowland Province } \\
\hline 7. & $\begin{array}{l}50^{\circ} 15^{\prime} 33^{\prime \prime} \mathrm{N}, 31^{\circ} 09^{\prime} 31^{\prime \prime} \mathrm{E} \\
7\end{array}$ & $\begin{array}{l}\text { Dark gray podzolized medium to low humusacumulative }+ \text { Chernozems podzolized } \\
\text { medium humusacumulative }\end{array}$ \\
\hline 8. & $\begin{array}{l}50^{\circ} 29^{\prime} 59^{\prime \prime} \mathrm{N} 31^{\circ} 14^{\prime} 47^{\prime \prime} \mathrm{E} \\
8\end{array}$ & $\begin{array}{l}\text { Meadow and chernozem-meadow surface-saline soils + Light gray podzolic soils + } \\
\text { Chernozems podzolized (Gleysols Sodic, Phaeozems Albic) }\end{array}$ \\
\hline \multicolumn{3}{|r|}{ Forest-Steppe, West Province } \\
\hline 9. & $\begin{array}{c}48^{\circ} 37^{\prime} 15^{\prime \prime} \mathrm{N} 25^{\circ} 44^{\prime} 15^{\prime \prime E} \\
1,6\end{array}$ & Chernozems podzolized + gray podzolic soils mainly on loessial rocks \\
\hline
\end{tabular}

\section{RESULTS}

Data on the detailed conditions and land parcels treated with studied pesticide formulation and its a.i. are presented in table 1. The actual levels of the different classes a.i. content in soil and its dynamics were determined, based on which the dissipation rate constants $(\mathrm{K})$ were calculated, as well as quantitative parameters of stability $\left(\tau_{50}, \tau_{95}, \tau_{99}\right)$. The results of the level of studied a.i. residues determined in the soil are shown in table 2.

Soil samples were collected 3 days after cereal crops treatment by studied formulations.

It should be noted that studied a.i. were not found in all soil control samples (i.e. less than relevant limits of detection (LODs) by appropriate chromatographic methods).

Having analyzed the data obtained in the studies of the level dynamics, it can be stated that a.i. residue concentrations in the studied samples were decreasing gradually.

A.i. behavior patterns in the soil from the experimental land parcels allocated for cereal crops were studied at the stage of treatment with formulations 1-9 by rod spraying method during the vegetative period

On the treatment day, residual amounts of the active ingredients of the $F$. 6 were determined at $0.11 \pm 0.02 \mathrm{mg} / \mathrm{kg}, 0.06 \pm 0.3009$ $\mathrm{mg} / \mathrm{kg}$ and $0.04 \pm 0.005 \mathrm{mg} / \mathrm{kg}$ levels for propiconazole, benzovindiflupyr, and cyproconazole, respectively. Since the day of treatment, the level of propiconazole in soil was below the TAC $(0.2 \mathrm{mg} / \mathrm{kg})$, while the level of cyproconazole passed this value only after 7 days $(0.01 \mathrm{mg} / \mathrm{kg})$. At the time of harvest (55 days for spring barley and 60 days for winter wheat and barley), no residual amounts of these active substances were found in the soil. The results offield studies that were obtained in determining the active substances of other pesticides (fungicides, herbicides and plant growth regulators) concentration levels in the soil were analyzed (F. 1, F. 4, F. 5, F. 7, F. 9, F. 2, F. 3, F. 8).

3 days after the treatment of winter wheat and barley crops with F. 1, the concentrations of azoxystrobin and cyproconazole in the soil were $0.025 \pm 0.004 \mathrm{mg} / \mathrm{kg}$ and $<0.01 \mathrm{mg} / \mathrm{kg}$, respectively, which in turn is less than the approved levels of TAC $(0.3 \mathrm{mg} / \mathrm{kg}$ for azoxystrobin and $0.01 \mathrm{mg} / \mathrm{kg}$ - for cyproconazole).

Field studies of the F. 4 behavior in the soil revealed that 3 days after treatment the concentration levels were $0.27 \pm 0.06$ $\mathrm{mg} / \mathrm{kg}$ for prochloraz, $0.1 \pm 0.05 \mathrm{mg} / \mathrm{kg}$ for epoxiconazole, respectively. On the 7 th day after treatment, the concentration of prochloraz was $0.18 \pm 0.02 \mathrm{mg} / \mathrm{kg}$, epoxiconazole $-0.03 \pm 0.01$ $\mathrm{mg} / \mathrm{kg}$, these values are lower than the established TAC for these a.i. (prochloraz $-0.3 \mathrm{mg} / \mathrm{kg}$, epoxiconazole $-0.4 \mathrm{mg} / \mathrm{kg}$ ).

When using F. 5, studies were conducted to determine the residual amounts of kresoxim-methyl and tebuconazole. The concentrations of kresoxim-methyl and tebuconazole 
Table 2. Content of a.i. in soil samples after pesticide formulation application on cereal spiked crops

\begin{tabular}{|c|c|c|c|c|}
\hline \multirow[t]{2}{*}{ Formulation } & \multirow[t]{2}{*}{ Active ingredient } & \multirow{2}{*}{$\begin{array}{l}\text { Standard in soil, tentatively } \\
\text { allowable concentration (TAC), } \\
\mathrm{mg} / \mathrm{kg}\end{array}$} & \multicolumn{2}{|c|}{$\begin{array}{l}\text { Content of a.i. in treated soil after ...days, } \\
\text { mg/kg: }\end{array}$} \\
\hline & & & 3 days & 7 days \\
\hline \multicolumn{5}{|c|}{ atn } \\
\hline \multirow{2}{*}{ F. 1} & azoxystrobin & 0,3 & $0,025 \pm 0,004$ & $0,012 \pm 0,002$ \\
\hline & cyproconazole & 0,01 & $<0,01$ & $<0,01$ \\
\hline \multirow{2}{*}{ F. 2} & picoxystrobin & 0,2 & $0,12 \pm 0,03$ & $0,1 \pm 0,03$ \\
\hline & cyproconazole & 0,01 & $0,04 \pm 0,01$ & $0,04 \pm 0,01$ \\
\hline F. 3 & pinoxaden & 0,3 & $0,11 \pm 0,03$ & $<0,1$ \\
\hline \multirow{2}{*}{ F. 4} & prochloraz & 0,3 & $0,27 \pm 0,06$ & $0,18 \pm 0,02$ \\
\hline & epoxiconazole & 0,4 & $0,1 \pm 0,05$ & $0,03 \pm 0,01$ \\
\hline \multirow{2}{*}{ F. 5} & tebuconazole & 1,0 & $0,09 \pm 0,01$ & $0,081 \pm 0,01$ \\
\hline & kresoxim-methyl & 0,1 & $0,056 \pm 0,008$ & $<0,05$ \\
\hline \multirow{3}{*}{ F. 6} & benzovindiflupyr & 0,03 & $0,041 \pm 0,008$ & $0,030 \pm 0,005$ \\
\hline & propiconazole & 0,2 & $0,08 \pm 0,01$ & $0,036 \pm 0,005$ \\
\hline & cyproconazole & 0,01 & $0,015 \pm 0,003$ & $<0,01$ \\
\hline \multirow{2}{*}{ F. 7} & azoxystrobin & 0,3 & $0,026 \pm 0,005$ & $<0,01$ \\
\hline & tebuconazole & 1,0 & $0,08 \pm 0,016$ & $0,072 \pm 0,01$ \\
\hline F. 8 & trinexapac-ethyl & 0,6 & $0,11 \pm 0,03$ & $<0,1$ \\
\hline \multirow{2}{*}{ F. 9} & azoxystrobin & 0,3 & $0,03 \pm 0,005$ & $<0,01$ \\
\hline & tebuconazole & 1,0 & $0,091 \pm 0,018$ & $<0.05$ \\
\hline \multirow{3}{*}{ F. 1} & & Aerial spraying & & \\
\hline & azoxystrobin & 0,3 & $0,01 \pm 0,002$ & $<0,01$ \\
\hline & cyproconazole & 0,01 & $<0,01$ & $<0,01$ \\
\hline \multirow{3}{*}{ F. 6} & benzovindiflupyr & 0,03 & $0,036 \pm 0,005$ & $<0,03$ \\
\hline & propiconazole & 0,2 & $0,11 \pm 0,01$ & $0,04 \pm 0,007$ \\
\hline & cyproconazole & 0,01 & $0,011 \pm 0,001$ & $<0,01$ \\
\hline
\end{tabular}

in soil were determined at 3 and 7 days after treatment. At 3 days the concentration levels of the studied a.i. were below the established TAC: the residual amount of kresoxim-methyl was $0.056 \pm 0.008 \mathrm{mg} / \mathrm{kg}$ (TAC $-0.1 \mathrm{mg} / \mathrm{kg}$ ), tebuconazole $-0.09 \pm 0.01 \mathrm{mg} / \mathrm{kg}$ (TAC $-1.0 \mathrm{mg} / \mathrm{kg}$ ).

Studies were also conducted to determine the residual amounts of azoxystrobin and tebuconazole (the a.i. of F. 7) in soil samples taken after winter wheat crop treatment. Determining the concentration of these substances, it was found that at 3 days after treatment, the level of azoxystrobin was $0.026 \pm 0.005 \mathrm{mg} / \mathrm{kg}$, tebuconazole $-0.08 \pm 0.016 \mathrm{mg} /$ $\mathrm{kg}$. At both the third and the seventh day, soil concentrations of azoxystrobin and tebuconazole were lower than the established TAC $(0.3 \mathrm{mg} / \mathrm{kg}$ and $1.0 \mathrm{mg} / \mathrm{kg}$, respectively).

After the application of the F. 9 preparation on the wheat crops, we determined the levels of a.i. concentration in soil samples picked from the treated area. Examining the concentrations of the substances presented, it was found that at 3 days after treatment the level of azoxystrobin was $0.03 \pm 0.005$ $\mathrm{mg} / \mathrm{kg}$, tebuconazole $-0.091 \pm 0.018 \mathrm{mg} / \mathrm{kg}$. At day 7 , azoxystrobin and tebuconazole were not determined (TAC for azoxystrobin is $0.3 \mathrm{mg} / \mathrm{kg}$, tebuconazole $-1.0 \mathrm{mg} / \mathrm{kg}$ ).
After cereal crops treatment with F. 3 herbicide, its active substance pinoxaden was determined in soil samples at the level of $0.11 \pm 0.03 \mathrm{mg} / \mathrm{kg}$ and $<0.1 \mathrm{mg} / \mathrm{kg}$ ( 3 and 7 days, respectively), which in turn is lower TAC $(0.3 \mathrm{mg} / \mathrm{kg})$.

On the third day after performed full-scale studies on the use of combined fungicide F. 2 it was found that the concentration of cyproconazole in the soil for both 3 and 7 days was $0.04 \pm 0.01 \mathrm{mg} / \mathrm{kg}$, the concentration of pyraclostrobin was determined at $0.12 \pm 0.03 \mathrm{mg} / \mathrm{kg}$ and $0.1 \pm 0.03 \mathrm{mg} / \mathrm{kg}$ on days 3 and 7 , respectively, which in turn is less than the previously established TAC $(0.2 \mathrm{mg} / \mathrm{kg})$. The concentration of cyproconazole at the time of harvest (40 days) was below the limit of determination of the relevant method.

3 days after the application of plant growth regulator F. 2 its active substance trinexepac-ethyl was determined at the level of $0.11 \pm 0.03 \mathrm{mg} / \mathrm{kg}$, at day $7-<0.1 \mathrm{mg} / \mathrm{kg}$, these findings indicate that a.i. were not exceeded soil TAC values $(0.6 \mathrm{mg} / \mathrm{kg})$.

We have also further investigated and analyzed the patterns of migration of active substances of the preparations F. 6 and F. 1 (azoxystrobin, benzovindiflupyr, propiconazole, and cyproconazole) in soil samples from the cereal crops area during aerial spraying. 
Table 3. The rate of the studied pesticides dissipation/disappearance in the soil

\begin{tabular}{|c|c|c|c|c|c|c|}
\hline \multirow{2}{*}{ Formulation } & \multirow{2}{*}{ Active ingredient } & \multicolumn{5}{|c|}{ Indices of dissipation/disappearance in soil } \\
\hline & & $\mathbf{k}^{-1}$ & $\tau_{50}$ & $\tau_{95}$ & $\tau_{99}$ & $\boldsymbol{\tau}_{50}^{*}$ \\
\hline \multicolumn{7}{|c|}{ Rod treatment } \\
\hline \multirow{2}{*}{ F. 1} & azoxystrobin & $\begin{array}{c}0,183 \pm \\
0,001\end{array}$ & $\begin{array}{c}3,757 \pm \\
0,020\end{array}$ & $\begin{array}{c}16,334 \pm \\
0,088\end{array}$ & $\begin{array}{c}25,045 \pm \\
0,135\end{array}$ & $120,9-261,9$ \\
\hline & cyproconazole & $\begin{array}{c}0,109 \pm \\
0,037\end{array}$ & $\begin{array}{c}8,305 \pm \\
3,121 \\
\end{array}$ & $\begin{array}{c}36,108 \pm \\
13,571\end{array}$ & $\begin{array}{c}55,365 \pm \\
20,809\end{array}$ & $62,1-501,2$ \\
\hline \multirow{2}{*}{ F. 2} & picoxystrobin & $\begin{array}{l}0,032 \pm \\
0,0022\end{array}$ & $\begin{array}{c}21,78 \pm \\
1,543\end{array}$ & $\begin{array}{c}94,68 \pm \\
6,708\end{array}$ & $\begin{array}{c}145,20 \pm \\
10,29\end{array}$ & $2,6-37,0$ \\
\hline & cyproconazole & $\begin{array}{l}0,058 \pm \\
0,0006\end{array}$ & $\begin{array}{c}11,90 \pm \\
0,068\end{array}$ & $\begin{array}{c}51,74 \pm \\
0,294\end{array}$ & $\begin{array}{c}79,33 \pm \\
0,451\end{array}$ & $62,1-501,2$ \\
\hline F. 3 & pinoxaden & $\begin{array}{l}0,052 \pm \\
0,0030\end{array}$ & $\begin{array}{l}13,07 \pm \\
0,4881\end{array}$ & $\begin{array}{c}56,82 \pm \\
2,122\end{array}$ & $\begin{array}{c}87,13 \pm \\
3,254\end{array}$ & $0,07-1,01$ \\
\hline \multirow{2}{*}{ F. 4} & prochloraz & $\begin{array}{c}0,098 \pm \\
0,017 \\
\end{array}$ & $\begin{array}{c}7,490 \pm \\
1,382 \\
\end{array}$ & $\begin{array}{c}32,562 \pm \\
6,007\end{array}$ & $\begin{array}{c}49,929 \pm \\
9,211 \\
\end{array}$ & $1,9-73,2$ \\
\hline & epoxiconazole & $\begin{array}{c}0,287 \pm \\
0,030\end{array}$ & $\begin{array}{c}2,464 \pm \\
0,280\end{array}$ & $\begin{array}{c}10,714 \pm \\
1,218\end{array}$ & $\begin{array}{c}16,428 \pm \\
1,868\end{array}$ & $44-226$ \\
\hline \multirow{2}{*}{ F. 5} & tebuconazole & $\begin{array}{c}0,027 \pm \\
0,002\end{array}$ & $\begin{array}{c}26,196 \pm \\
1,772\end{array}$ & $\begin{array}{c}113,893 \pm \\
7,705\end{array}$ & $\begin{array}{c}174,637 \pm \\
11,815\end{array}$ & $25,8-91,6$ \\
\hline & kresoxim-methyl & $\begin{array}{c}0,061 \pm \\
0,019\end{array}$ & $\begin{array}{c}14,300 \pm \\
5,146\end{array}$ & $\begin{array}{c}62,176 \pm \\
22,375\end{array}$ & $\begin{array}{c}95,334 \pm \\
34,307\end{array}$ & $1-3$ \\
\hline \multirow{3}{*}{ F. 6} & benzovindiflupyr & $\begin{array}{c}0,098 \pm \\
0,001 \\
\end{array}$ & $\begin{array}{c}7,036 \pm \\
0,079 \\
\end{array}$ & $\begin{array}{c}30,560 \pm \\
0,344\end{array}$ & $\begin{array}{c}46,910 \pm \\
0,527 \\
\end{array}$ & $0,001-336^{* *}$ \\
\hline & propiconazole & $\begin{array}{c}0,161 \pm \\
0,003\end{array}$ & $\begin{array}{c}4,287 \pm \\
0,090\end{array}$ & $\begin{array}{c}18,637 \pm \\
0,389 \\
\end{array}$ & $\begin{array}{c}28,577 \pm \\
0,596 \\
\end{array}$ & $15,3-96,3$ \\
\hline & cyproconazole & $\begin{array}{c}0,192 \pm \\
0,011\end{array}$ & $\begin{array}{c}3,621 \pm \\
0,218\end{array}$ & $\begin{array}{c}15,744 \pm \\
0,946\end{array}$ & $\begin{array}{c}24,140 \pm \\
1,451\end{array}$ & $62,1-501,2$ \\
\hline \multirow{2}{*}{ F. 7} & azoxystrobin & $\begin{array}{c}0,236 \pm \\
0,028\end{array}$ & $\begin{array}{c}3,016 \pm \\
0,375\end{array}$ & $\begin{array}{c}13,113 \pm \\
1,631\end{array}$ & $\begin{array}{c}20,113 \pm \\
2,496\end{array}$ & $120,9-261,9$ \\
\hline & tebuconazole & $\begin{array}{c}0,024 \pm \\
0,009\end{array}$ & $\begin{array}{c}43,546 \pm \\
21,838\end{array}$ & $\begin{array}{c}189,329 \pm \\
94,948 \\
\end{array}$ & $\begin{array}{c}290,307 \pm \\
145,585 \\
\end{array}$ & $25,8-91,6$ \\
\hline F. 8 & trinexapac-ethyl & $\begin{array}{l}0,047 \pm \\
0,0002\end{array}$ & $\begin{array}{c}14,75 \pm \\
0,04676\end{array}$ & $64,13 \pm 0,2033$ & $98,33 \pm 0,3117$ & $6,9-21$ \\
\hline \multirow{2}{*}{ F. 9} & azoxystrobin & $\begin{array}{c}0,122 \pm \\
0,018\end{array}$ & $\begin{array}{c}5,957 \pm \\
1,006\end{array}$ & $\begin{array}{c}25,898 \pm \\
4,376\end{array}$ & $\begin{array}{c}39,710 \pm \\
6,709\end{array}$ & $120,9-261,9$ \\
\hline & tebuconazole & $\begin{array}{c}0,034 \pm \\
0,005\end{array}$ & $\begin{array}{c}20,973 \pm \\
2,820\end{array}$ & $\begin{array}{c}91,188 \pm \\
12,261\end{array}$ & $\begin{array}{c}139,821 \pm \\
18,799 \\
\end{array}$ & $25,8-91,6$ \\
\hline \multicolumn{7}{|c|}{ Aerial spraying } \\
\hline \multirow{2}{*}{ F. 1} & azoxystrobin & $\begin{array}{c}0,066 \pm \\
0,019\end{array}$ & $\begin{array}{c}12,042 \pm \\
2,710\end{array}$ & $\begin{array}{c}52,359 \pm \\
11,781\end{array}$ & $\begin{array}{c}80,283 \pm \\
18,065\end{array}$ & $120,9-261,9$ \\
\hline & cyproconazole & $\begin{array}{c}0,109 \pm \\
0,037\end{array}$ & $\begin{array}{c}8,305 \pm \\
3,121\end{array}$ & $\begin{array}{c}36,108 \pm \\
13,571\end{array}$ & $\begin{array}{c}55,365 \pm \\
20,809\end{array}$ & $62,1-501,2$ \\
\hline \multirow{3}{*}{ F. 6} & benzovindiflupyr & $\begin{array}{c}0,069 \pm \\
0,017\end{array}$ & $\begin{array}{c}11,416 \pm \\
3,157\end{array}$ & $\begin{array}{c}49,636 \pm \\
13,726\end{array}$ & $\begin{array}{c}76,108 \pm \\
21,046\end{array}$ & $0,001-336^{* *}$ \\
\hline & propiconazole & $\begin{array}{c}0,202 \pm \\
0,005\end{array}$ & $\begin{array}{c}3,423 \pm \\
0,079\end{array}$ & $\begin{array}{c}14,880 \pm \\
0,341\end{array}$ & $\begin{array}{c}22,820 \pm \\
0,526\end{array}$ & $15,3-96,3$ \\
\hline & cyproconazole & $\begin{array}{c}0,094 \pm \\
0,012\end{array}$ & $\begin{array}{c}7,629 \pm \\
1,062\end{array}$ & $\begin{array}{c}33,171 \pm \\
4,616\end{array}$ & $\begin{array}{c}50,862 \pm \\
7,078\end{array}$ & $62,1-501,2$ \\
\hline
\end{tabular}

Footnotes: 1. «k-1» - dissipation rate constant (days); 2 . «T50» - time for disappearance of half the chemical (days); 3 . «T95» - time for disappearance of $95 \%$ of the chemical (days); 4 . «T99» - time for disappearance of $99 \%$ of the chemical (days) 5. «*» - reference data [12-13] 6. «** 
Starting 3 days after cereal crops treatment with F. 6, the level of propiconazole content in the soil was $0.11 \pm 0.01 \mathrm{mg} /$ $\mathrm{kg}$ and, accordingly, was lower than the TAC level -0.2 $\mathrm{mg} / \mathrm{kg}$, the content of benzovindiflupyr and cyproconazole was $0.036 \pm 0.005 \mathrm{mg} / \mathrm{kg}$ and $0.011 \pm 0.001 \mathrm{mg} / \mathrm{kg}$, respectively. On day 7 , benzovindiflupyr and cyproconazole were determined in the soil below the limit of quantification $(0.03 \mathrm{mg} / \mathrm{kg}$ and $0.01 \mathrm{mg} / \mathrm{kg}$, respectively), and the value for cyproconazole was lower than the TAC $(0.01 \mathrm{mg} / \mathrm{kg})$.

3 days after F. 1 application on winter wheat and barley crops $\mathrm{f}$, the concentrations of azoxystrobin and cyproconazole in the soil were $0.01 \pm 0.002 \mathrm{mg} / \mathrm{kg}$ and $<0.01 \mathrm{mg} /$ $\mathrm{kg}$ (below the limit of quantification), respectively. This, in turn, is less than the established TAC levels (for azoxystrobin is $0.3 \mathrm{mg} / \mathrm{kg}$, and cyproconazole $-0.01 \mathrm{mg} / \mathrm{kg}$ ).

For a more detailed evaluation of the data we obtained, several mathematical analyzes of the degradation processes of the studied a.i. were conducted, using an exponential model using the first-order kinetics equation $[9,10]$.

The results of the conducted studies to determine the level of residual content of the a.i. in the soil (Table 3 ) allowed us to calculate the dissipation rate constant $(\mathrm{K})$ and quantitative parameters of substances persistency in environmental objects using the least-squares method: decay periods by $50 \%, 95 \%$ and $99 \%\left(\tau_{50}, \tau_{95}\right.$, and $\left.\tau_{99}\right)$

\section{DISCUSSION}

The value of azoxystrobin $\tau_{50}$ in different agro-climatic conditions of Ukraine ranges from 3.03 to 12.04 days, these findings differ from those established in the European region $[11,12]$. The half-life of azoxystrobin in parcel site (p.s.) 9 soils is significantly faster compared to a similar process in p.s. 4 and p.s. 6 ( $\mathrm{p} \leq 0.05)$.

During the experiments, it was found that the half-life of kresoxim-methyl in p.s. 5 passes in $14.3 \pm 5.15$ days. The half-life of another representative of the strobilurins class - picoxystrobin in p.s. 1 was $21.78 \pm 1.543$ days.

$\tau_{50}$ of benzovindiflupyr for p.s. 6 and p.s. 9 soils is 7.04 and 11.42 days, respectively, and does not have significant differences ( $\mathrm{p} \geq 0.05$ ). Benzovindiflupyr biodegradation processes in Ukraine's agro-climatic conditions are faster than in the European region $[13,15]$.

Studying the features of the degradation processes of triazoles (epoxiconazole, propiconazole, tebuconazole, and cyproconazole) in the soil, it was found that the halflife of the substances presented is: for epoxiconazole $\tau_{50}$ $-2.47 \pm 0.28$ days; for propiconazole $\tau_{50}-3.85 \pm 0.19$ days; for cyproconazole $\tau_{50}-7.95 \pm 1.04$ days; for tebuconazole $\tau_{50}-30.19 \pm 7.15$ days. Propiconazole half-lives $\left(\tau_{50}\right)$ for p.s. 6 and p.s. 9 areas are $3.62 \pm 0.22$ and $7.63 \pm 1.06$ days, respectively. Propiconazole was found to decompose significantly faster in p.s. $6(\mathrm{p} \leq 0,05)$.

Determining the degradation processes for the active substance prochloraz under in-field conditions, we obtained the following results: $50 \%$ decay in p.s. 3 soils occurs at $7.49 \pm 1.38$ days.

Also during the experiments, it was found that the half-life of pinoxaden in p.s. 3 soils is $13.07 \pm 0.49$ days. And the half- life of trinexapac-ethyl in p.s. 8 soils was $14.75 \pm 0.047$ days.

The differences in the degradation rates of the studied active substances, which were calculated for individual areas, can be associated with different types of soils and climate and weather conditions, it should be noted that the rate of neutralization of active chemical compounds in the soil depends on its $\mathrm{pH}$ value, atmospheric parameters of air, namely humidity and temperature, solar activity (the intensity of ultraviolet radiation), as well as the amount of active substance applied [14-16]. According to the Hygienic Classification of Pesticides by the Degree of Hazard currently in force in Ukraine, by the soil persistence in the agro-climatic conditions of Ukraine azoxystrobin, benzovindiflupyr, epoxiconazole, propiconazole, prochloraz, cyproconazole can be classified as of low hazardous substances (gradeIV), and trinexapac-ethyl, kresoxim-methyl, picoxystrobin, and tebuconazole are considered to be moderately hazardous (grade III). Among all pesticides studied, tebuconazole is the longest persists in the soil; epoxiconazole and propiconazole are most likely to disappear from the soil.

\section{CONCLUSIONS}

It should be noted that our calculated values of half-lives of the studied substances in the agro-climatic conditions of Ukraine are slightly different from the results of infield experiments that were conducted in other countries, namely: azoxystrobin, epoxiconazole, propiconazole, and cyproconazole disappear from the soil more quickly; the kresoxim-methyl and pinoxaden disappear more slowly [12].

Meanwhile, the persistence of benzovindiflupyr, picoxystrobin, prochloraz, trinexapac-ethyl, and tebuconazole in the agro-climatic conditions of Ukraine does not differ from the persistence in soils of European countries [11].

\section{REFERENCES}

1. Goncharuk E.I. Hygienic significance of soil concerning the health status of the population. Gigiena i sanitariia. 1990; 4:4-7.

2. Karpenko 0., Muravkina M. Assessment of ecological \& economic consequences of ineffective use of pesticides on regional level. Economic innovations: Coll. Science. pr. Odessa: IPREED NAS of Ukraine. 2012; 48:140-149.

3. Rather I.A., Koh W.Y., Paek W.K., Lim J. The Sources of Chemical Contaminants in Food and Their Health Implications. Front Pharmacol. 2017;8:830.

4. Thiele-Bruhn S., Schloter M., Wilke B.-M., Beaudette L. A. et al. Identification of new microbial functional standards for soil quality assessment. SOIL. 2020; 6(1): 17-34.

5. Onwona-Kwakye M., Plants-Paris K., Keita K., Lee J., et al. Pesticides Decrease Bacterial Diversity and Abundance of Irrigated Rice Fields. Microorganisms, 2020; 8(3).

6. GFM Network News. (2018, August 16). Ralph Pearce: Multiple modes of action an emerging reality for fungicides. https://www.grainews. ca/daily/pearce-multiple-modes-of-action-an-emerging-reality-forfungicides/

7. Development of pesticide resistance in pests: status of the problem and prospects for its solution. https://agrodovidka.info/post/2842.

8. Soil map of Ukraine - SuperAgronom.com. (n.d.). Retrieved March 03,2020. https://superagronom.com/karty/karta-gruntiv-ukrainy. 
9. GoncharukY., Sydorenko G., Sanitary Standards of Chemical Substances in Soil: Methodic Guidelines. 1986; 360.

10. Recommendations for calculations of levels and changes with the time of agrochemical toxicants in soil and in plants: approved 20 Feb. 1987. Moscow: State Agriculture Industry Committee of the USSR, 1987; 57.

11. University of Hertfordshire. (n.d.). The PPDB is a comprehensive relational database of pesticide chemical identity, physicochemical, human health and ecotoxicological data. Retrieved February 12 - March 13, 2020. https://sitem.herts.ac.uk/aeru/ppdb/en/atoz.htm.

12. EFSA Journal. (n.d.). The EFSA Journal is an open access, online scientific journal that publishes the scientific outputs of the European Food Safety Authority. Retrieved February 12-March 13, 2020. https://efsa. onlinelibrary.wiley.com/journal/18314732/.

13. ELATUS PLUS. Registration Report Central Zone: Part B - Section 5 Core Assessment. Germany. 2017; 13-15.

14. Saroya A. Handbook of Phytopharmacology. Scientific Publishers. 2008; 264.

15. K. Sytnyk, Bahnjuk V. Stan gruntiv I majbutnje ljudstva [Soil state and humanity future]. Visn. Nac. Akad. Nauk Ukr., 2008; 8:1-8. (in Ukrainian).

16. Pal R., Chakrabarti K., Chakraborty A. and Chowdhury A. Degradation and Effects of Pesticides on Soil Microbiological Parameters - A Review. International Journal of Agricultural Research. 2006;240:258.

\section{ORCID and contributionship:}

AnnaV. Blagaia: 0000-0002-2451-9689 A, C, D

Mykola V. Kondratiuk: 0000-0001-5500-6352 ${ }^{\text {B, C }}$

Sergii T. Omelchuk: 0000-0003-3678-4241 ${ }^{F}$

Ihor M. Pelo: 0000-0002-4764-102X ${ }^{E}$

Nataliia D. Kozak: 0000-0002-8599-3165 ${ }^{\mathrm{E}}$

\section{Conflict of interest:}

The Authors declare no conflict of interest.

\section{CORRESPONDING AUTHOR}

\section{AnnaV. Blagaia}

Bogomolets National Medical University

13 T. Shevchenko boulevard, 01601 Kyiv, Ukraine

tel: +380442344062

e-mail: profilactika@hotmail.com

Received: 15.04 .2020

Accepted: 31.08 .2020

A - Work concept and design, B - Data collection and analysis, C - Responsibility for statistical analysis,

D-Writing the article, $\mathbf{E}$-Critical review, $\mathbf{F}$ - Final approval of the article 